\title{
Litter Production, Decomposition, and Nutrient Release in Subalpine Forest Communities of the Northwest Himalaya
}

\author{
Vinod K. Bisht, ${ }^{1}$ Bhagwati P. Nautiyal, ${ }^{2}$ Chandra P. Kuniyal, \\ P. Prasad, ${ }^{3}$ and Rakesh C. Sundriyal ${ }^{4}$ \\ ${ }^{1}$ Herbal Research and Development Institute, Mandal, Gopeshwar, Uttarakhand 246401, India \\ ${ }^{2}$ Institute of Medicinal and Aromatic Plants, University of Horticulture and Forestry, Mehalchauri, Chamoli, \\ Uttarakhand 246431, India \\ ${ }^{3}$ High Altitude Plants Physiology Research Centre, HNB Garhwal (Central) University, Srinagar, Garhwal, Uttarakhand 246174, India \\ ${ }^{4}$ GB Pant Institute of Himalayan Environment and Development, Kosi-Katarmal, Almora, Uttarakhand 243643, India
}

Correspondence should be addressed to Vinod K. Bisht; vksbisht@gmail.com

Received 11 July 2014; Revised 30 September 2014; Accepted 23 October 2014; Published 18 November 2014

Academic Editor: Nicholas Clarke

Copyright (C) 2014 Vinod K. Bisht et al. This is an open access article distributed under the Creative Commons Attribution License, which permits unrestricted use, distribution, and reproduction in any medium, provided the original work is properly cited.

Production, decomposition, and release of nutrients from leaf and nonleaf litter were investigated in four subalpine forests of North-West Himalaya, India. Total annual litter fall in four communities varied from 2950.00 to $4040.00 \mathrm{~kg} \mathrm{ha}^{-1}$ and was found significant $\left(\mathrm{CD}_{0.05}=118.2\right)$. Decomposition of leaf litter varied from 1.82-3.5\% during autumn-winter to 36.14-45.51 during summer rainy season in all stands and percent of mass loss was significantly varied in stands $\left(\mathrm{CD}_{6.00}\right)$. Similarly, decomposition in nonleaf litter was varied from $0.3-1.1 \%$ during autumn-winter to $19.59-30.05 \%$ during summer rainy season and was significantly varied irrespective of seasons. However, percent decomposition of leaf litter and the values of decay constant $(k)$ were at par in all stands. Total standing state of nutrients in fresh litter as well as release of total nitrogen $(\mathrm{N})$, phosphorus $(\mathrm{P})$, and potassium $(\mathrm{K})$ in due course of decomposition (12 months) was also varying significantly. The rate of nonleaf litter decomposition was significantly positively correlated with air temperature ( $r=0.63-0.74$ in all communities). The significant correlation $(r=0.85)$ was observed only in Rhododendron-Sorbus forest community (PRS). Study indicates that the air temperature is a major determinant for nonleaf litter decomposition in this region.

\section{Introduction}

Subalpine forests represent a transition zone between alpine areas and temperate forest communities [1] and shared floristic components of alpine and lower temperate zone. Thus, subalpine forests are the habitat specialized with key governing factors such as harsh environmental conditions including low soil and air temperatures, massive snowfall, scanty precipitation, and diurnal variations in the temperatures for ecosystem functioning. Notable shift in the vegetational pattern at subalpine region appears in the form of cessation of tree limit and beginning of alpine meadows those harbours herbaceous and complex mosaic of plant communities. Thus, subalpine habitats are indicators for presence of specific environmental and edaphic determinant. Majority of subalpine forests in the Northwestern Himalaya are sensitive to topography, anthropogenic interferences, and abrupt climatic changes [2].

The integrity of an ecosystem is maintained by the transfer of matter and energy between producers, consumers, and decomposers [3]. A major part of the annual gain of energy and matter is shed as litter [4] which enters into the decomposition subsystem as dead organic matter or detritus. The organic matter on the forest floor is a major source of energy for heterotrophic organisms and mineral nutrients for plant growth and significantly affects hydrology and ecosystem structure and function [5]. As decomposition of plant litter is central to many ecosystem functions such 
as soil formation and nutrient cycling [6,7], a thorough understanding of this process is essential in understanding the functioning of terrestrial ecosystems.

The importance of forest floor components to site productivity is well known. The decomposition of forest litter is the foremost pathway for providing organic and inorganic elements for the nutrient cycling processes and maintenance of soil nutrient pool $[6,8]$. Litter production and decomposition is a key process in biogeochemical process of forest ecosystem and varies with climate, season, substrate quality, and type of biota [9-12]. Chemical composition, amount of lignin, nitrogen, hemicelluloses, and secondary compounds are the variable for affecting decomposition [10]. Total litter fall is composed of leaf litter and nonleaf litter. The decay rate of leaf litter and nonleaf litter also varies [13]. In general, nonleaf litter decays slowly but it also provides habitats for fungi, bacteria, arthropods, and invertebrates [14].

The quantity of nutrients released in a unit area or in particular ecosystem is known to be dependent on the quality of biomass accumulated. Decomposition of litter is a sequential process whereby complicated organic compounds are continuously degraded into simpler substances, releasing nutrients as byproduct of their breakdown [15]. To comprehend its dynamics, it is important to start with the chemical composition of plant litter as litter chemistry is the main determinant of litter decomposition $[8,16]$ within a given climatic region followed by rate of decomposition and nutrient release to soil organic pool. However, little is known regarding litter production, rate of decomposition, and releases of these main nutrients to soil organic matter pool through various types of leaf litter forms in subalpine forests of Northwestern Himalaya.

Very few studies are available on the litter fall, factor associated with decomposition and nutrient release in the subalpine areas of Northwestern Himalaya [1, 8, 17-19]. In view of functional ecological attributes, subalpine areas in the Northwestern Himalaya are among the least investigated habitats; however, it is very important to monitor these areas for estimating the possible change in future [2]. Therefore, present communication reports (i) litter production in different forest types in subalpine area, (ii) disappearance rate and standing state of main macronutrients [total nitrogen $(\mathrm{N})$, potassium $(\mathrm{K})$, and phosphorus $(\mathrm{P})$ ] of litter, and (iii) release pattern of macronutrients through litter decomposition to soil organic matter pool.

\section{Material and Method}

2.1. Study Area. The Panar, a subalpine region in Chamoli district (Uttarakhand, North-West Himalaya, India) in the vicinity of Kedarnath Wildlife Sanctuary, was selected for this study (Figure 1). Varied topography with diverse vegetation consisting of broad leaf, conifers, and deciduous trees in this region provides an immense scope to explore functional aspects of the community. Geographically, this region is characterized by rugged and deep gorges, gullies, and moderate to steep slopes. Most of the region is towards south to southeast aspects. Floristic diversity, geographical structure, and altitudinal gradients in this region are unique. Along $3200 \pm 100 \mathrm{~m}$ asl, a recognizable demarcation of tree line and alpine meadows is apparent. In general, the region experienced two seasons, that is, the winter season during October to March (autumn-winter season) and summer season during April to September (summer rainy season). The winter season commences with heavy frosting (OctoberDecember) followed by heavy snow fall (January-February) and the area remains under snow cover till the end of March [20]. The air temperature increases thereafter followed by heavy rainfall during July-September. The summer season therefore is favourable for plant growth. Mean minimum and maximum air temperatures during April to September were 2.96 and $14.80^{\circ} \mathrm{C}$ (Figure 2). Temperature may also drop to subzero during winter nights. Relative humidity during the study period was recorded approximately $70-94 \%$. Sporadic premonsoon showers coupled with occasional hailstorms are also experienced in May and June. On the basis of ambient conditions this habitat may be categorized as "moist temperate subalpine."

Plant communities in the subalpine forests are stratified along an altitudinal gradient. In the subalpine areas of the Northwestern Himalaya, some conifers such as Abies spectabilis and Taxus baccata thrive well in association with broad leaved species including Acer caesium, Sorbus microphylla, Rhododendron arboreum, $R$. campanulatum, Betula utilis, and oaks (i.e., Quercus floribunda and Q. semecarpifolia). Spatial distribution and regeneration pattern of forest types in this subalpine area was studied by Bisht et al. [20]. Based on dominant tree species and their combinations, this region was divided into 4 stands for present study, namely, (1) Acer-Rhododendron (abbreviated as PAR, P for Panar), (2) Quercus-Quercus (PQQ), (3) Abies-Quercus (PAQ), and (4) Rhododendron-Sorbus (PRS) (Figure 3). Approximately $200 * 200 \mathrm{~m}$ area was marked in each stand $(n=4)$ and stratified by a distance of $30 \pm 5$ meters for the observation on litter production and soil analysis.

2.2. Physico-Chemical Analysis. From each stand, soil was collected at $0-10 \mathrm{~cm}, 10-20 \mathrm{~cm}$ and $20-30 \mathrm{~cm}$ depth and composited. Soil texture classes were determined by following the textural triangle, while soil colors were determined with reference to Munsell's soil color chart (Munsell Color Division, Kollmorgen Corporation, Baltimore, MD 24218, USA, 1971). Soil moisture content (\%) and soil water holding capacity (\%) were estimated by following Goel and Trivedi [21] gravimetrically. Soils $\mathrm{pH}$ was estimated using an electrometric $\mathrm{pH}$ meter (Environmental and Scientific Instrument Corporation, Model-1012 E). Total nitrogen (N\%), available phosphorus ( $\mathrm{P} \%)$, and exchangeable potassium $(\mathrm{K} \%)$ were estimated using the methods of Allen [22], Olsen et al. [23], and Jackson [24], respectively. The details of ecological and climatic parameters with physicochemical characteristics of soils in the study area are described earlier (see Bisht et al. [20]) and also given in Table 1.

2.3. Litter Standing Crop. Total litter fall was estimated using three randomly placed nylon litter traps of $1 * 1 \mathrm{~m}$ 


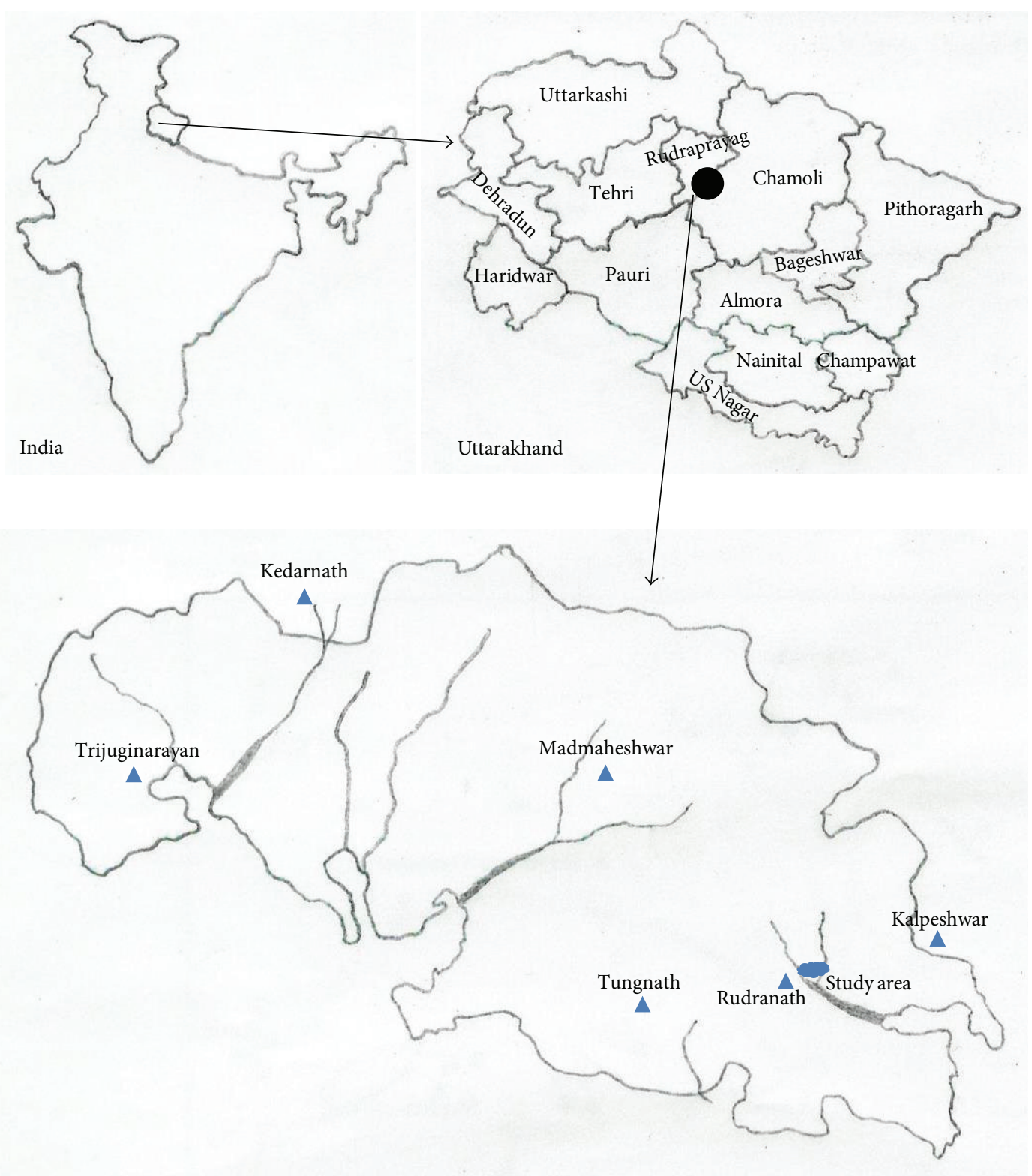

FIgURE 1: Important alpine meadows and study area in KWLS.

dimension with $30 \mathrm{~cm}$ inner depth in triplicate which were fixed randomly $25 \mathrm{~cm}$ above ground in all 4 stands in the first week of October 2009 before the commencement of snow fall. Retrieving of litter twice a year was done, that is, after snow melt (first week of March, 2010) and prior to frost and snow fall (late September, 2010) to estimate annual litter production. Retrieved litter was segregated as leaf litter and nonleaf litter including twigs, seeds/cones, and bark and wood remains. In order to estimate the total litter fall during autumn-winter and summer rainy seasons, retrieved litter was oven dried at $55 \pm 2^{\circ} \mathrm{C}$. Annual litter fall in selected stands was weighed and converted to $\mathrm{kg} \mathrm{ha}^{-1}$.

2.4. Assessment of Litter Decomposition. In another set of experiments, litter of different ligneous species was collected from the yellow senescent leaves, branches, twigs, and other parts of plants prior to abscission or recently abscised from each forest stand and was cleaned with a soft cloth to remove adhering debris. The litter was then air dried. Equal weights $(200 \mathrm{~g})$ of leaf litter and nonleaf litter were placed in nylon mesh bags measuring $38.1 * 50.8 \mathrm{~cm}$ ( $1 \mathrm{~mm}$ mesh) on the floor of each stand during the first week of October, 2009, following Witkamp and van der Drift [25]. Experiment was designed to observe litter decomposition for a year (November 2009October 2010). Decomposition rate was assessed under snow during winter months (i.e., October 2009-March 2010) and summer rainy seasons (i.e., April-October 2010). A total of 24 bags ( 8 months $\times 3$ replicates) of each litter type in each stand were prepared. Overall, 192 bags were placed in randomized block disign in all 4 stands. The first batch of 
TABLE 1: Geography and soil characteristics of selected stands in subalpine region.

\begin{tabular}{|c|c|c|c|c|}
\hline \multirow[b]{2}{*}{ Parameters } & \multicolumn{4}{|c|}{ Forest stands } \\
\hline & $\begin{array}{c}\text { Acer-Rhododendron } \\
\text { (PAR) }\end{array}$ & $\begin{array}{l}\text { Quercus-Quercus } \\
\text { (PQQ) }\end{array}$ & $\begin{array}{c}\text { Abies-Quercus } \\
\text { (PAQ) }\end{array}$ & $\begin{array}{l}\text { Rhododendron-Sorbus } \\
\text { (PRS) }\end{array}$ \\
\hline $\begin{array}{l}\text { Mean elevation } \\
\text { (m asl) }\end{array}$ & 3265 & 3293 & 3304 & 3383 \\
\hline Location & $\begin{array}{l}30^{\circ} 28^{\prime} 03^{\prime \prime}-30^{\circ} 28^{\prime} 08^{\prime \prime} \mathrm{N} \\
79^{\circ} 20^{\prime} 35^{\prime \prime}-79^{\circ} 20^{\prime} 46^{\prime \prime} \mathrm{E}\end{array}$ & $\begin{array}{l}30^{\circ} 28^{\prime} 29^{\prime \prime}-30^{\circ} 28^{\prime} 32^{\prime \prime} \mathrm{N} \\
79^{\circ} 21^{\prime} 10^{\prime \prime}-79^{\circ} 21^{\prime} 20^{\prime \prime} \mathrm{E}\end{array}$ & $\begin{array}{l}30^{\circ} 28^{\prime} 25^{\prime \prime}-30^{\circ} 28^{\prime} 33^{\prime \prime} \mathrm{N} \\
79^{\circ} 21^{\prime} 30^{\prime \prime}-79^{\circ} 21^{\prime} 39^{\prime \prime} \mathrm{E}\end{array}$ & $\begin{array}{l}30^{\circ} 28^{\prime} 19^{\prime \prime}-30^{\circ} 28^{\prime} 25^{\prime \prime} \mathrm{N} \\
79^{\circ} 20^{\prime} 59^{\prime \prime}-79^{\circ} 21^{\prime} 01^{\prime \prime} \mathrm{E}\end{array}$ \\
\hline Aspect & North & South & South-East & South \\
\hline \multirow{2}{*}{ Forest type } & Moist temperate & Moist temperate & Moist temperate & Moist temperate \\
\hline & Semievergreen & Evergreen & Evergreen & Semievergreen \\
\hline \multicolumn{5}{|l|}{ Species richness } \\
\hline Woody species & 4 & 2 & 4 & 4 \\
\hline Herbaceous species & 9 & 10 & 8 & 9 \\
\hline \multicolumn{5}{|l|}{ Density $\left(\mathrm{ha}^{-1}\right)$} \\
\hline Woody species & 750 & 690 & 640 & 1,260 \\
\hline Herbaceous species & 76,000 & 71,000 & 56,000 & 111,000 \\
\hline Dominant species* & $\begin{array}{c}\text { Acer caesium (54.67), } \\
\text { Rhododendron arboreum } \\
\text { (37.33) }\end{array}$ & Quercus floribunda (96.87) & $\begin{array}{c}\text { Abies spectabilis (47.83), } \\
\text { Quercus semecarpifolia } \\
(49.27)\end{array}$ & $\begin{array}{c}\text { Rhododendron } \\
\text { campanulatum (79.44), } \\
\text { Sorbus microphylla (18.18) }\end{array}$ \\
\hline $\begin{array}{l}\text { Other associated } \\
\text { species }\end{array}$ & $\begin{array}{c}\text { Litsea elongata, } \\
\text { Taxus baccata }\end{array}$ & Quercus semecarpifolia & $\begin{array}{l}\text { Quercus floribunda, Taxus } \\
\text { baccata }\end{array}$ & Betula utilis, Taxus baccata \\
\hline \multicolumn{5}{|l|}{ Soil } \\
\hline Soil texture & Sandy loam & Loam & Sandy loam & Loam \\
\hline Soil colour & Reddish brown & Brown & Dark brown & Brown to dark brown \\
\hline Soil moisture (\%) & $55.41 \pm 6.07$ & $48.78 \pm 7.38$ & $49.67 \pm 6.16$ & $51.37 \pm 6.80$ \\
\hline WHC (\%) & $69.44 \pm 5.26$ & $66.58 \pm 6.87$ & $69.47 \pm 7.09$ & $70.87 \pm 6.49$ \\
\hline $\mathrm{pH}$ & $6.65 \pm 0.29$ & $6.66 \pm 0.22$ & $6.45 \pm 0.43$ & $6.66 \pm 0.15$ \\
\hline $\mathrm{N}(\%)$ & $0.69 \pm 0.13$ & $0.58 \pm 0.15$ & $0.59 \pm 0.23$ & $0.52 \pm 0.15$ \\
\hline $\mathrm{P}\left(\mathrm{Kg} \mathrm{ha}^{-1}\right)$ & $13.33 \pm 5.79$ & $13.47 \pm 3.29$ & $10.87 \pm 2.86$ & $10.12 \pm 3.73$ \\
\hline $\mathrm{K}\left(\mathrm{Kg} \mathrm{ha}^{-1}\right)$ & $245.10 \pm 26.66$ & $233.00 \pm 28.59$ & $249.81 \pm 25.64$ & $251.46 \pm 20.73$ \\
\hline $\mathrm{OC}(\%)$ & $1.99 \pm 0.30$ & $2.30 \pm 0.32$ & $2.26 \pm 0.44$ & $2.19 \pm 0.24$ \\
\hline
\end{tabular}

${ }^{*}$ Values in parenthesis are percent of total stand density, ${ }^{*} \pm$-S.E., $n=8$.

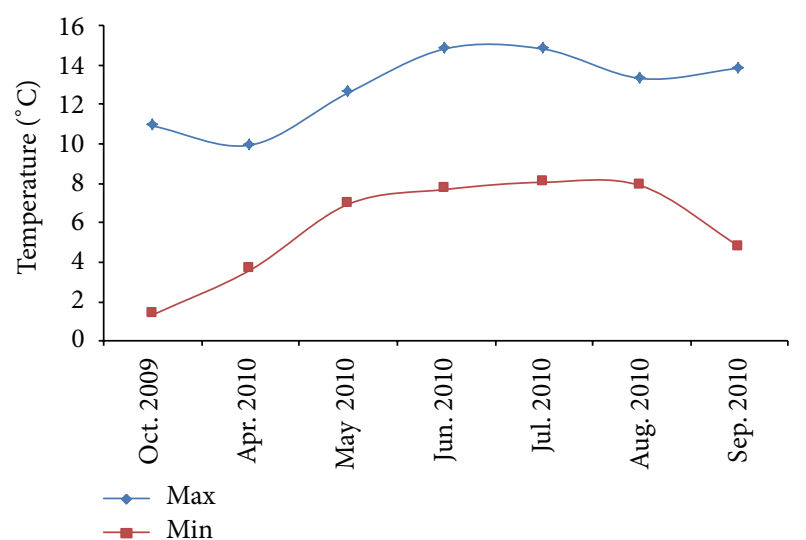

FIgURE 2: Average daily minimum and maximum temperature at Panar subalpine-timberline area during April 2010 to October 2010. litter bags from each forest stand were recovered (in triplicate) in March, 2010, immediately after snow melt in the area to assess the rate of decomposition under snow. Thereafter, litter bags were retrieved monthly from April to October, 2010, for the growth period. Retrieved litter bags were brought to the laboratory in sealed polyethylene bags. After using soft cloth to remove fine soil particles, litter samples were oven dried at $55 \pm 2^{\circ} \mathrm{C}$ until constant weight was recorded. Dry weights of samples were recorded (Digital electronic balance XX-7301A, Anamed Instrumentation Pvt. Ltd.). The litter decomposition rate $(R)$ for the time period (month) and decay constant $(k)$ for the annual rate of decomposition was calculated following Sangha et al. [10] as

$$
R=X o-\frac{X t}{X o} * t, \quad \frac{X t}{X o}=e^{-k t}
$$




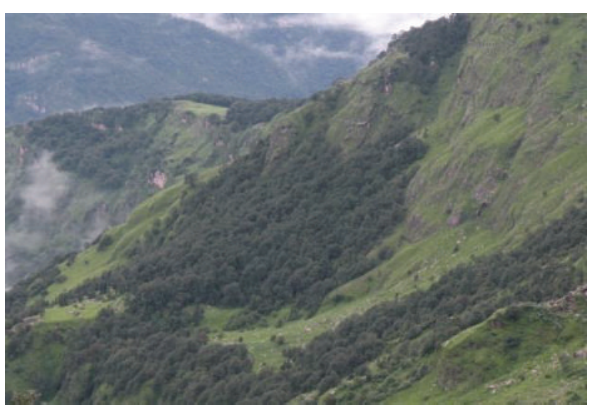

(a)

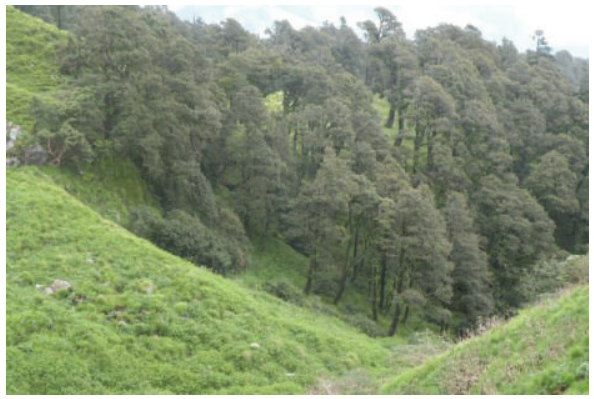

(c)

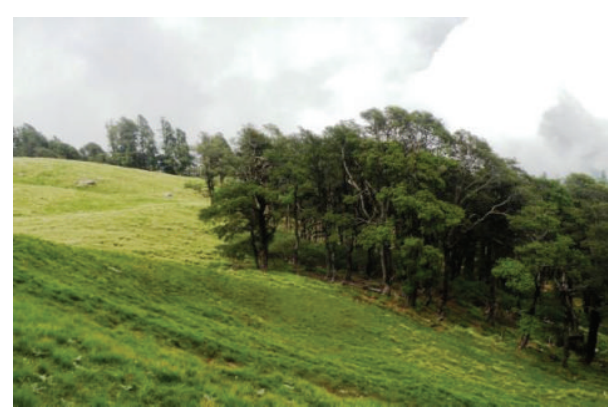

(b)

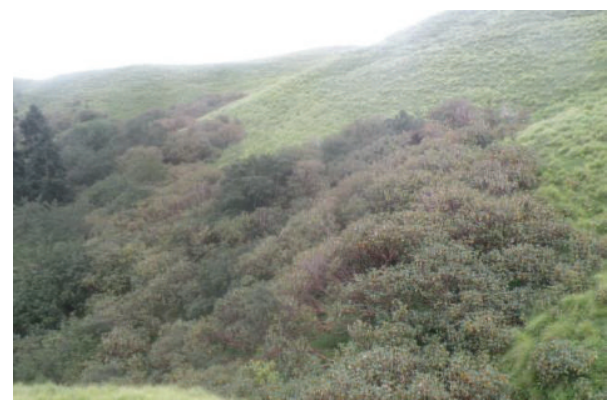

(d)

FIgURE 3: Four stands of the study area, namely, PAR, PQQ, PAQ, and PRS.

where $X o$ is original weight of litter for decomposition $(\mathrm{g})$, $X t$ is weight of litter remaining at time period $t, k$ is decay constant, and $t$ is time period (12 months for $k$ ).

2.5. Nutrients Release Pattern. To estimate the monthly release of nutrients, oven dried $\left(55 \pm 2^{\circ} \mathrm{C}\right)$ initial litter of both litter types as well as litter retrieved from the field was powdered and analysed for nitrogen $(\mathrm{N})$, phosphorus $(\mathrm{P})$, and potassium $(\mathrm{K})$ as per the methods of $[22,24$, 26], respectively. Standing stock of nutrients for each forest stand was calculated as litter standing crop multiplied by nutrient contents of litter. The amount of nutrient release was calculated by subtracting the amount of nutrient present after decomposition at time $t$ from that of initial nutrient stock.

2.6. Data Analysis. The data obtained from different observations were subjected to analysis of variance (ANOVA) using randomized block design. Significance of the variance $(P=0.05)$ due to time interval and between stands was determined by calculating the respective $F$ value and then critical difference [27]. Similarly, correlation coefficient $(r)$ between temperature and humidity with mass loss through decomposition in due course of observation was also analyzed by using linear correlation regression analysis.

\section{Results}

3.1. Litter Production. Observations on litter fall reveal that annual litter fall ranged from $2950 \mathrm{~kg} \mathrm{ha}^{-1}$ (PAR) to $4040 \mathrm{~kg} \mathrm{ha}^{-1}$ (PRS) $\left(\mathrm{CD}_{0.05}=118.2\right)$ although, independently for leaf litter and nonleaf litter, there were no significant differences. Annually, leaf litter contributed $75-79 \%$ of total litter production compared to nonleaf litter in the stands with no significant difference among stands. Marked seasonal variations were noted in the amount of litterfall (leaf litter and nonleaf litter) with being higher during the summer rainy season compared to autumn-winter. Of the total litterfall, leaf litter contributed (62-78\%) in autumn-winter season. The contribution of leaf litter increased (80-85\%) in comparison to nonleaf litter in summer rainy season (Table 2).

3.2. Decomposition Rate. Decomposing leaf litter lost 1.8$3.5 \%$ of original mass during autumn-winter and 36.1$45.5 \%$ during summer rainy season in all stands. The mean monthly decomposition during summer rainy season (MayOctober) varied from 6.0\% (PQQ) to 7.6\% (PRS) (Figure 4). However, mass loss from leaf litter varied significantly $\left(\mathrm{P}_{0.05}\right)$ among stands in both seasons (Table 3). Standing state of nutrients varied significantly in fresh litter (Table 4). The decomposition of leaf litter in stands with Abies (PAQ) and Rhododendron (PAR) was found less sensitive to air temperature and humidity as indicated in Table 5. Decomposition of nonleaf litter was 0.3 (PQQ)-1.1\% (PRS) during autumnwinter season; nevertheless variation in decomposition rate $(k)$ as well as mass loss $\left(\mathrm{CD}_{0.05}=0.7\right)$ among stands was found significant. During summer rainy season, decomposition rate $(k)$ as well as mass loss was lower than leaf litter but then variation in mass loss among stands was found significant $\left(\mathrm{CD}_{0.05}=11.8\right)$.

It appears from Table 3 that $37-47$ percent of original litter decomposed after a year in all stands even if the variation in decomposing litter between the stands was significant $\left(\mathrm{CD}_{0.05}=6.0\right)$. Comparatively, less nonleaf litter 


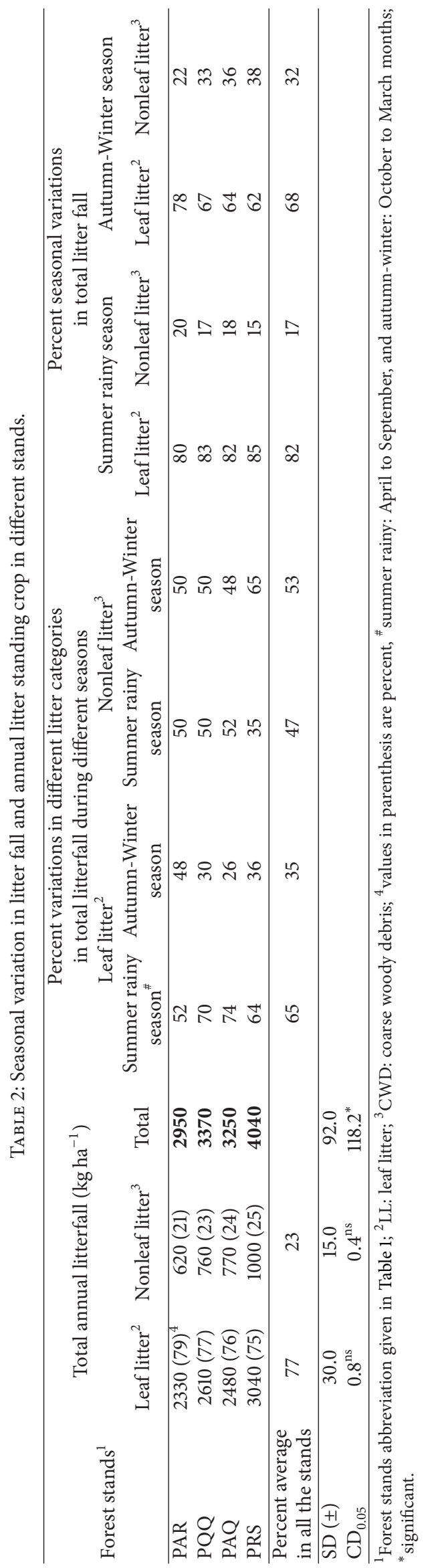




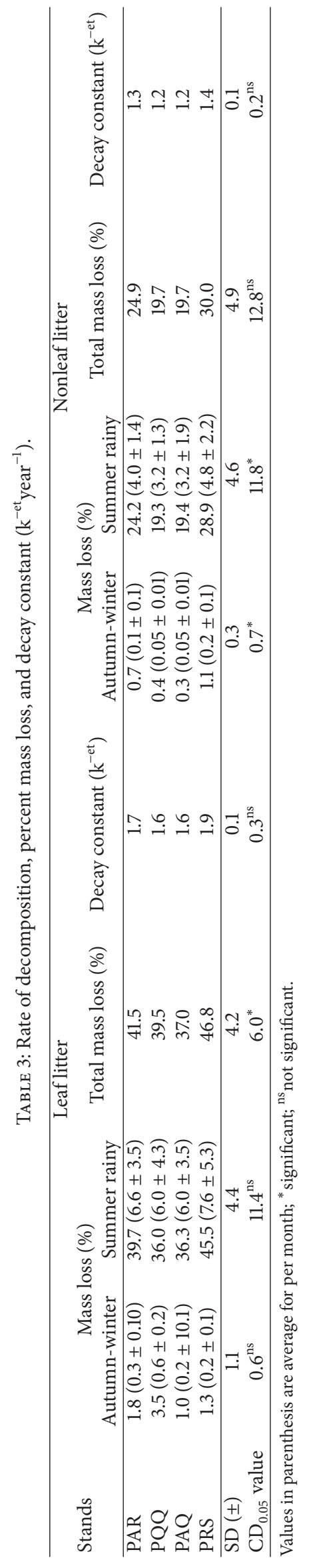


TABLE 4: Standing state of nutrients in fresh litter and \% release after 1 year of decomposition ${ }^{+}$.

\begin{tabular}{|c|c|c|c|c|c|c|c|c|c|}
\hline \multirow[b]{2}{*}{ Stands } & \multicolumn{3}{|c|}{ Total nitrogen } & \multicolumn{3}{|c|}{ Potassium } & \multicolumn{3}{|c|}{ Phosphorus } \\
\hline & $\begin{array}{c}{ }^{*} \mathrm{~N} \text { standing } \\
\text { stock } \\
\left(\mathrm{kg} \mathrm{ha}^{-1}\right) \\
\end{array}$ & $\begin{array}{c}{ }^{+} \text {Initial } \\
\text { concentration } \\
(\mathrm{g} / \mathrm{kg})(\mathrm{Yi})\end{array}$ & $\begin{array}{l}{ }^{\#} \mathrm{TN} \\
\text { released } \\
(\%)(\mathrm{Yd})\end{array}$ & $\begin{array}{c}{ }^{*} \mathrm{~K} \text { standing } \\
\text { stock } \\
\left(\mathrm{kg} \mathrm{ha}^{-1}\right)\end{array}$ & $\begin{array}{c}{ }^{+} \text {Initial } \\
\text { concentration } \\
(\mathrm{g} / \mathrm{kg})(\mathrm{Yi})\end{array}$ & $\begin{array}{c}{ }^{\#} \mathrm{~K} \text { released } \\
(\%)(\mathrm{Yd})\end{array}$ & $\begin{array}{c}{ }^{*} \mathrm{P} \text { standing } \\
\text { stock } \\
\left(\mathrm{kg} \mathrm{ha}^{-1}\right) \\
\end{array}$ & $\begin{array}{c}{ }^{+} \text {Initial } \\
\text { concentration } \\
(\mathrm{g} / \mathrm{kg})(\mathrm{Yi}) \\
\end{array}$ & $\begin{array}{l}{ }^{\#} \mathrm{P} \text { released } \\
(\%)(\mathrm{Yd})\end{array}$ \\
\hline PAR & 65 & 22.2 & 20.1 & 43.9 & 14.9 & 8.9 & 6.2 & 2.1 & 1.7 \\
\hline PQQ & 83 & 24.6 & 22.8 & 51.2 & 15.1 & 7.5 & 8.8 & 2.6 & 2.0 \\
\hline PAQ & 79 & 23.5 & 24.4 & 46.1 & 14.2 & 7.1 & 7.5 & 2.3 & 2.3 \\
\hline PRS & 93 & 23.1 & 21.8 & 59.4 & 14.7 & 8.0 & 12.5 & 3.1 & 2.5 \\
\hline Sd & 11.6 & 1.0 & 1.8 & 6.9 & 0.4 & 0.8 & 2.7 & 0.4 & 0.3 \\
\hline $\begin{array}{l}\mathrm{CD}_{0.05} \\
\text { value }\end{array}$ & $15.4^{\circ}$ & $0.2^{\bullet}$ & $2.3^{\circ}$ & $8.8^{\circ}$ & $0.1^{\circ}$ & $1.0^{\circ}$ & $3.5^{\circ}$ & $0.1^{\circ}$ & $0.4^{\circ}$ \\
\hline
\end{tabular}

${ }^{*}$ Indicates standing state of litter nutrients in selected forest types; ${ }^{+}$initial concentration in fresh litter kept for decomposition; ${ }^{\#}$ percent of initial concentration ${ }^{+}$ released from decomposed litter after 12 months; ${ }^{*}$ significant.

TABLE 5: Relationship between decomposition rate and climatic data.

\begin{tabular}{|c|c|c|c|c|c|c|c|c|}
\hline \multirow{4}{*}{ Stands } & \multicolumn{8}{|c|}{ Correlation coefficient $(r)^{\#}$} \\
\hline & \multicolumn{4}{|c|}{ Temperature } & \multicolumn{4}{|c|}{ Humidity } \\
\hline & \multicolumn{2}{|c|}{$\begin{array}{l}\text { Decomposition rate } \\
\text { of leaf litter }\end{array}$} & \multicolumn{2}{|c|}{$\begin{array}{c}\text { Decomposition rate } \\
\text { of nonleaf litter }\end{array}$} & \multicolumn{2}{|c|}{$\begin{array}{l}\text { Decomposition rate } \\
\text { of leaf litter }\end{array}$} & \multicolumn{2}{|c|}{$\begin{array}{c}\text { Decomposition rate } \\
\text { of nonleaf litter }\end{array}$} \\
\hline & $r$ & $\%$ variation & $r$ & $\%$ variation & $r$ & $\%$ variation & $r$ & $\%$ variation \\
\hline PAR & ns & 7.0 & 0.7 & 55.0 & ns & 1.0 & ns & 9.0 \\
\hline PQQ & ns & 24.0 & 0.6 & 40.0 & ns & 7.0 & ns & 12.0 \\
\hline PAQ & ns & 0.0 & 0.6 & 41.0 & ns & 1.0 & ns & 9.0 \\
\hline PRS & 0.6 & 41.0 & 0.7 & 52.0 & $\mathrm{~ns}$ & 20.0 & 0.8 & 72.0 \\
\hline
\end{tabular}

\#Significant level: $P<0.05$.

was decomposed in all stands with no significant variation $\left(\mathrm{CD}_{0.05}=12.8\right)$ and the value of per cent mass loss ranged from 19.6 to 30.0 . The decay constant $(k)$ year $^{-1}$ reflected the slower decay rate especially for nonleaf litter where it was at par in all stands and ranged from 1.24 (PQQ and PAQ) to $1.42 \mathrm{~kg} \mathrm{ha}^{-1}$ (PRS). For LL, although variation in $k$ values of stands was not significant and ranged from 1.6 (PAQ) to $1.9 \mathrm{~kg} \mathrm{ha}^{-1}$ (PRS), it was reported to be slightly higher than the values for nonleaf litter. This indicates high decay rate of leaf litter over nonleaf litter. During this study, decomposition rate of nonleaf litter was significantly correlated with air temperature in all stands $\left(r_{0.05}=0.63-0.74\right)$ and with the rate of leaf litter decomposition in PRS. However, relationship between decomposition rate and humidity was not significant (Table 5).

3.3. Standing Stock and Release Pattern of Nutrients. The total standing state of $\mathrm{N}$ ranged between 64.5 and $93.3 \mathrm{~kg} \mathrm{ha}^{-1}$, $\mathrm{P}$ between 6.2 and $12.5 \mathrm{kgha}^{-1}$, and $\mathrm{K}$ between 43.9 and $59.4 \mathrm{~kg} \mathrm{ha}^{-1}$ in different stands (Table 4; Figures 5-7). In general, fresh litter of stand PRS showed a maximum content of all nutrients probably due to broad leaf litter of Rhododendron and even Sorbus.

During decomposition, $\mathrm{N}$ concentration from leaf litter declined by $0.9 \pm 0.1 \%$ to $1.4 \pm 0.1 \%$ in different stands during summer rainy months while it ranged only between
0.7 and $1.0 \%$ in winter. Similarly, N concentration declined from nonleaf litter ranged between $1.1 \pm 1.0 \%$ and $2.5 \pm 1.5 \%$ at all stands. Decline in $\mathrm{N}$ concentration in leaf litter was low compared to nonleaf litter at selected stands during all months (Figure 4). Similarly, P from leaf litter declined from $0.1 \pm 0.01$ to $0.1 \pm 0.01 \%$ while it was $0.1 \pm 0.1 \%$ to $0.2 \pm$ $0.16 \%$ from nonleaf litter (Figure 5). The values of decline in $\mathrm{K}$ concentration from leaf litter ranged from $0.3 \pm 0.02 \%$ to $0.6 \pm 0.1 \%$ and from nonleaf litter it followed the same trend in all stands (Figure 6).

\section{Discussion}

Annual litter standing crop, contribution by leaf litter and nonleaf litter to total litter, and litter production were similar in all stands irrespective of vegetation composition. However, litter production in different forest stands in present subalpine region was at lower site as reported by Tripathi et al. [28] and Pandey et al. [29]. Seasonal quantity and quality of total litter production during this study follow the model of litter production correlated to climatic factors [30]. As usual, the broad leaved deciduous species returned slightly higher quantity of leaf litter compared to the conifer species mixed habitats. However, the variations in standing state of leaf litter and nonleaf litter dropped to the ground were not significant within seasons or among stands. In general leaf litter contributes around $70 \%$ of annual litter production 


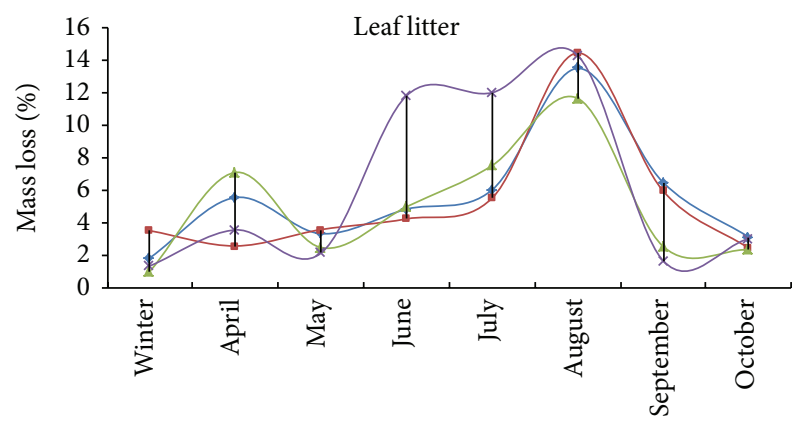

Summer rainy

(a)

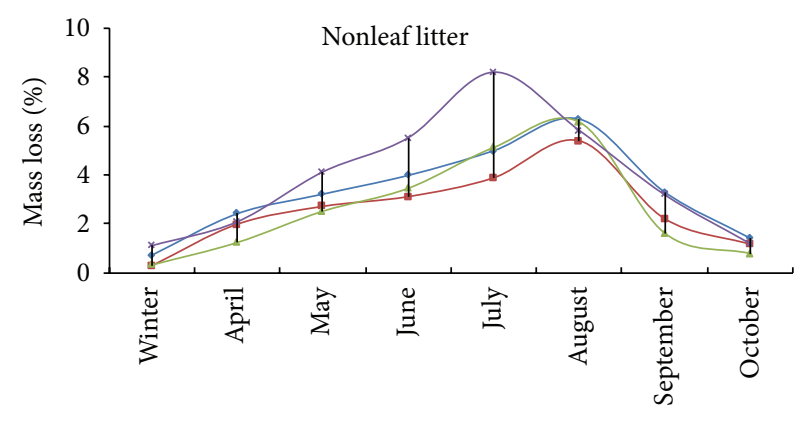

Summer rainy

$$
\begin{array}{ll}
\rightarrow \text { PAR } & \rightarrow \text { PAQ } \\
\rightarrow \text { PQQ } & \star \text { PRS }
\end{array}
$$

(b)

Figure 4: Percent mass loss of decomposing litter during different months/season.

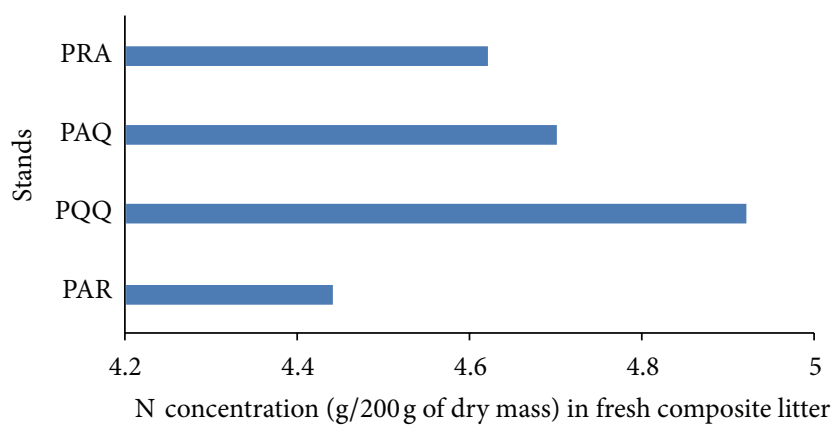

(a)

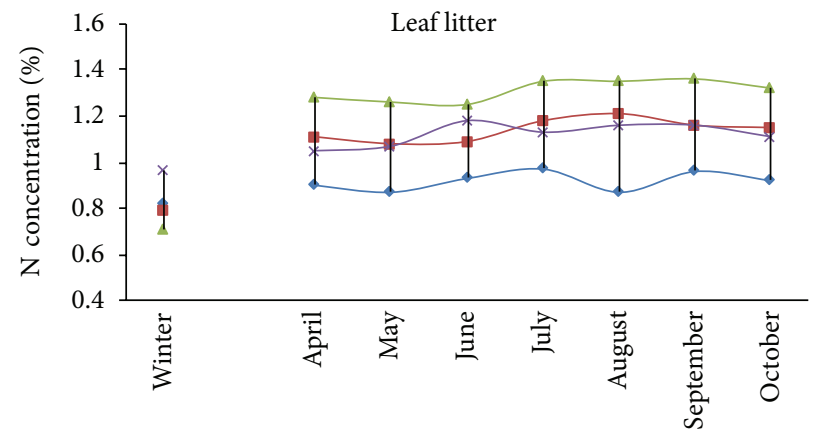

Summer rainy

$$
\begin{array}{ll}
\rightarrow \text { PAR } & \leftarrow \text { PAQ } \\
\rightarrow \text { PQQ } & \rightarrow \text { PRS }
\end{array}
$$

(b)

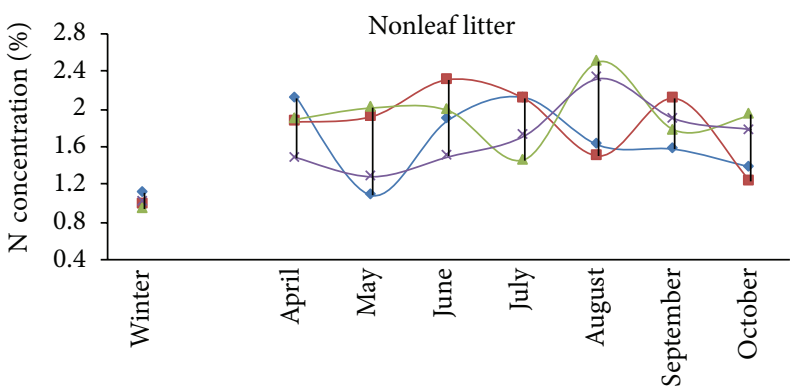

Summer rainy

$$
\begin{array}{ll}
\rightarrow \text { PAR } & \star \\
\rightarrow \text { PQQ } & \star \text { PAQ }
\end{array}
$$

(c)

FIGURE 5: Initial N concentration of fresh litter and seasonal variation in total nitrogen concentration in decomposing litter.

in cold temperate habitats [31]. In the subalpine regions of Himalaya, leaf litter is reported to be the major contributor (67-81\%) in total annual litter production [1]. However, on seasonal basis, nonleaf litter contributes more to total litter production during autumn-winter than during summer rainy season. This may be attributed to the presence of Acer caesium (PAR) and Sorbus macrophylla (PRS), which are deciduous and shed their leaves and twigs during autumn-winter season. Besides, nonleaf litter also includes seeds/fruits.

Litter decomposition and nutrient fluxes depend mainly on litter chemistry and plant types in a given climatic region $[29,32]$. Significant variation in percent decomposition of nonleaf litter (Table 3 ) irrespective of season may be attributed to litter chemistry. 


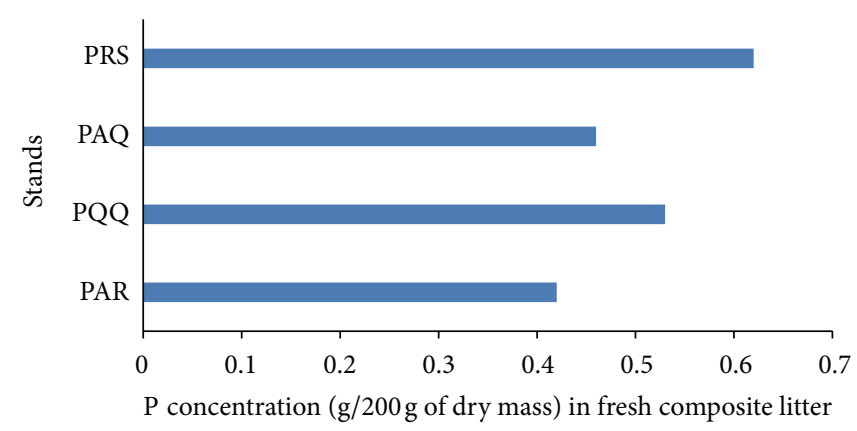

(a)

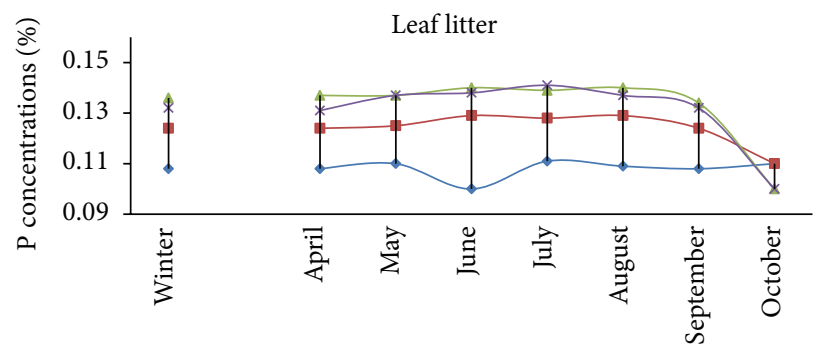

Summer rainy

$\begin{array}{ll}\rightarrow \text { PAR } & \rightarrow \text { PAQ } \\ \rightarrow \text { PQQ } & \star-\text { PRS }\end{array}$

(b)

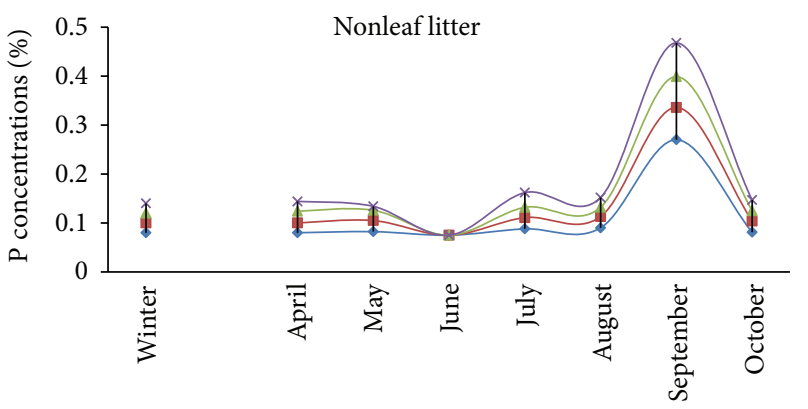

Summer rainy

$\because$ PAR

$\rightarrow$ PAQ

$\approx$ PRS

(c)

FIgURE 6: Initial P content of fresh litter and seasonal variation in total P concentration in decomposing litter.

It is believed that litter decomposition is generally low in the forests across the globe under cold climate [3]. The rate of litter decomposition significantly correlated to the air temperatures, precipitation and moisture contents in the litter [33, 34], and abundance of macro-detrivores such as invertebrates and arthropods [35]. Low temperatures are known to retard activity of soil microbes [36]. Slow decomposition of litter during autumn-winter may attribute to this phenomenon. In present study, higher rate of decomposition was observed in both the litter types during summer rainy season. Alhamd et al. [37] reported that activity of decomposers is also favoured by high temperatures and high relative humidity. However, easily decomposable litter of tree species may undergo rapid mass loss at the initial stages of decomposition [4].

The decomposition of leaf litter in stands with Abies (PAQ) and Rhododendron (PAR) was found less sensitive to air temperature and humidity. This might be due to higher lignin content that made litter somewhat complex in terms of readily available quality [38]. Beyond 30\% decomposition, lignin content becomes increasingly important for further decomposition [39].

Significant variation in standing state of nutrients may primarily be due to different vegetation composition and dominance of one or a few tree species in all stands. Also, release of all 3 minerals varied significantly in all stands. The variation in release of $\mathrm{N}$ from both types of decomposing litter may vary due to higher fungal activity which increases $\mathrm{N}$ content in decomposing litter [40]. Pande et al. [41] reported $\mathrm{N}$ as the most important factor in leaf litter decomposition in an Oak-Conifer forest. Higher $\mathrm{N}$ content initially promotes decomposition and later on has suppressing effect due to the impedance created by its presence on lignin degrading enzymes [42]. The standing state of $\mathrm{K}$ was higher than $\mathrm{P}$. However, percent release of $\mathrm{P}$ was higher. The litter of high altitude species is rich in $\mathrm{P}$ content as compared to the low altitude species and releases $\mathrm{P}$ continuously during decomposition [18]. Potassium-litter chemistry is poorly documented so far but major flux is via canopy leaching [43]. However, low obtainability of $\mathrm{N}$ along with $\mathrm{P}$ in litter could be one of the reasons of slow decomposition rate as described by Berg and Laskowski [44].

In general, abiotic factors (like precipitation, temperature), composition of microbial and plant species, and altered chemical composition of stand types were major determinant for the release of nutrients during the course of decomposition [7, 8, 10,45]. Nevertheless, comparatively a small amount of the nutrients present in original above ground litter was transferred to the soil through disappearance and decomposition of aboveground litter as also reported by Rawat et al. [7] and Rawat et al. [8] for alpine ecosystem of Northwestern Himalaya. Litter shed by subalpine forests does not decompose completely in the subsequent favourable season and layers of litter are deposited on the floor of the forests which are subsequently replaced from the system through runoff during rainy season. 


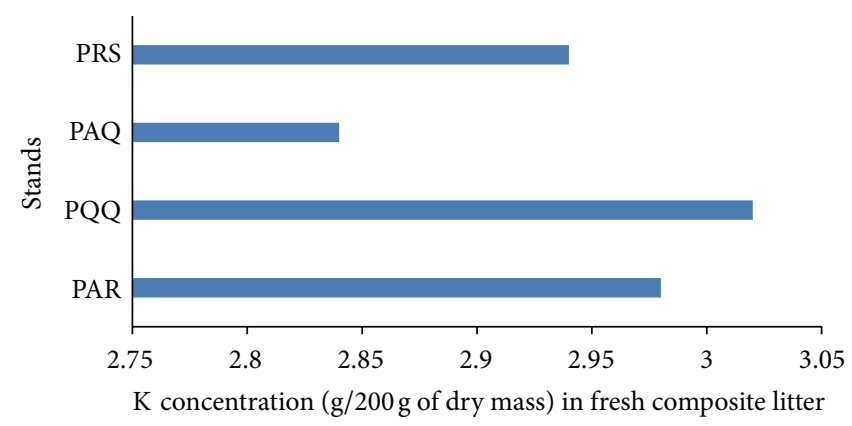

(a)

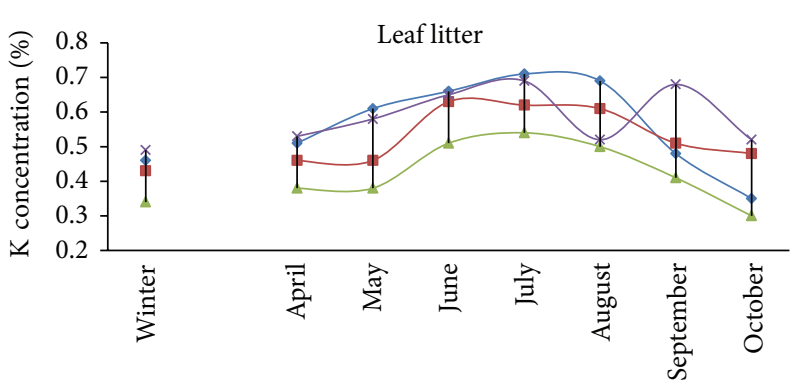

Summer rainy

$\begin{array}{ll}\rightarrow \mathrm{PAR} & \rightarrow \mathrm{PAQ} \\ \rightarrow \mathrm{PQQ} & \rightarrow \mathrm{PRS}\end{array}$

(b)

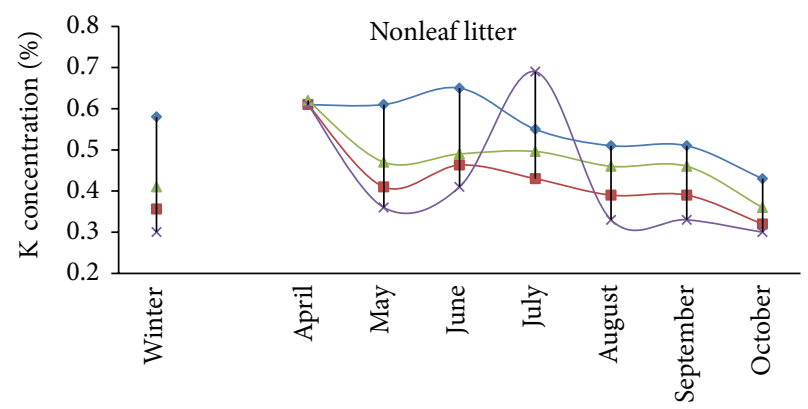

Summer rainy

$\begin{array}{ll}\rightarrow \text { PAR } & \rightarrow \text { PAQ } \\ \rightarrow \text { PQQ } & \rightarrow \text { PRS }\end{array}$

(c)

FIGURE 7: Initial K content of fresh litter and seasonal variation in total $\mathrm{K}$ concentration in decomposing litter.

\section{Conclusion}

Annual litter fall, seasonal decomposition, and nutrient releases patterns in the four sites at a subalpine habitat of Northwestern Himalaya indicated the following. (i) Leaflitter is a major contributor in the total litter fall; however, some species may also shed the tender twigs and variety of other nonleaf litter during autumn-winter. (ii) Decomposition of the litter was noted to be better during favourable season (i.e., summer rainy). Based on above observations, it can be concluded that comparatively small amount of the nutrients present in original above ground litter was transferred to the soil through disappearance and litter decomposition.

\section{Conflict of Interests}

The authors declare that there is no conflict of interests regarding the publication of this paper.

\section{Acknowledgments}

The authors are thankful to Director of Herbal Research and Development Institute, Mandal, Gopeshwar, and Director of High Altitude Plant Physiology Research Centre, Srinagar, Garhwal, for providing necessary facilities.

\section{References}

[1] S. Gairola, R. S. Rawal, and U. Dhar, "Patterns of litterfall and return of nutrients across anthropogenic disturbance gradients in three subalpine forests of West Himalaya, India," Journal of Forest Research, vol. 14, no. 2, pp. 73-80, 2009.

[2] I. Rai, B. Adhikari, and G. S. Rawat, "Mass foliar damage at subalpine-timberline ecotone in Western Himalaya due to extreme climatic events," American Journal of Climate Change, vol. 1, no. 2, pp. 104-107, 2012.

[3] C. E. Prescott, L. L. Blevins, and C. Staley, "Litter decomposition in British Columbia forests: controlling factors and influences of forestry activities," Journal of Ecosystems and Management, vol. 5, no. 2, pp. 44-57, 2004.

[4] X. Xu and E. Hirata, "Decomposition patterns of leaf litter of seven common canopy species in a subtropical forest: $\mathrm{N}$ and $\mathrm{P}$ dynamics," Plant and Soil, vol. 273, no. 1-2, pp. 279-289, 2005.

[5] T. Christensen, "Wood litter fall in relation to abscission, environmental factors and the decomposition cycle in Danish Oak forest," Oikos, vol. 26, pp. 187-195, 1975.

[6] S. Y. Yu, F. G. Jian, S. C. Guang, S. X. Jin, P. C. Li, and P. Lin, "Litterfall, nutrient return, and leaf-litter decomposition in four plantations compared with a natural forest in subtropical China," Annals of Forest Science, vol. 61, no. 5, pp. 465-476, 2004.

[7] N. Rawat, B. P. Nautiyal, and M. C. Nautiyal, "Annual nutrients budget for the grazed and ungrazed sites of an alpine expanse in North-West Himalaya, India," The Environmentalist, vol. 30, no. 1, pp. 54-66, 2010. 
[8] N. Rawat, B. P. Nautiyal, and M. C. Nautiyal, "Litter decomposition rate and nutrient release from different litter forms in a Himalayan alpine ecosystem," Environmentalist, vol. 30, no. 3, pp. 279-288, 2010.

[9] P. M. Vitousek, D. R. Turner, W. J. Parton, and R. L. Sanford, "Litter decomposition on the mauna loa environmental matrix, Hawai'i: patterns, mechanisms, and models," Ecology, vol. 75, no. 2, pp. 418-429, 1994.

[10] K. K. Sangha, R. K. Jalota, and D. J. Midmore, "Litter production, decomposition and nutrient release in cleared and uncleared pasture systems of central Queensland, Australia," Journal of Tropical Ecology, vol. 22, no. 2, pp. 177-189, 2006.

[11] R. Aerts, "Climate, leaf litter chemistry and leaf litter decomposition in terrestrial ecosystems: a triangular relationship," Oikos, vol. 79, no. 3, pp. 439-449, 1997.

[12] M. J. Swift, O. W. Heal, and J. M. Anderson, Decomposition in Terrestrial Ecosystems, vol. 5 of Studies in Ecology, Blackwell Scientific, Oxford, UK, 1979.

[13] G. K. Ganjegunte, L. M. Condron, P. W. Clinton, M. R. Davis, and N. Mahieu, "Decomposition and nutrient release from radiata pine (Pinus radiata) coarse woody debris," Forest Ecology and Management, vol. 187, no. 2-3, pp. 197-211, 2004.

[14] A. Sarjubala Devi and P. S. Yadava, "Wood and leaf litter decomposition of Dipterocarpus tuberculatus Roxb. in a tropical deciduous forest of Manipur, Northeast India," Current Science, vol. 93, no. 2, pp. 243-246, 2007.

[15] V. Yadav and G. Malanson, "Progress in soil organic matter research: litter decomposition, modelling, monitoring and sequestration," Progress in Physical Geography, vol. 31, no. 2, pp. 131-154, 2007.

[16] B. Hoorens, R. Aerts, and M. Stroetenga, "Does initial litter chemistry explain litter mixture effects on decomposition?" Oecologia, vol. 137, no. 4, pp. 578-586, 2003.

[17] V. P. Upadhyay and J. S. Singh, "Decomposition of woody branch litter on an altitudinal transect in the Himalaya," Vegetatio, vol. 64, no. 2-3, pp. 49-53, 1986.

[18] V. P. Upadhyay, J. S. Singh, and V. Meentemeyer, "Dynamics and weight loss of leaf litter in Central Himalayan forests: abiotic versus litter quality influences," Journal of Ecology, vol. 77, no. 1, pp. 147-161, 1989.

[19] B. S. Majila, G. C. Joshi, and C. P. Kala, "Patterns in litter fall and litter decomposition along an altitudinal gradient in the Binsar Wildlife Sanctuary, Central Himalaya," International Journal of Sustainable Development and World Ecology, vol. 12, no. 2, pp. 205-212, 2005.

[20] V. K. Bisht, C. P. Kuniyal, B. P. Nautiyal, and P. Prasad, "Spatial distribution and regeneration of Quercus semecarpifolia and Quercus floribunda in a subalpine forest of western Himalaya, India," Physiology and Molecular Biology of Plants, vol. 19, no. 3, pp. 443-448, 2013.

[21] P. K. Goel and R. K. Trivedi, Chemical and Biological Methods for Water Pollution, Soil and Plant Analysis, Environment Publications, Karad, India, 1st edition, 1992.

[22] E. Allen, Chemical Analysis of Ecological Material, Blackwell Scientific, Oxford, UK, 1974.

[23] S. R. Olsen, C. V. Cole, F. S. Watanabe, and L. A. Dean, "Estimation of available Phosphorus in soils by extraction with sodium bicarbonate," USDA Circuler 939, US Government Print Office, Washington, DC, USA, 1954.

[24] M. L. Jackson, Soil Chemical Analysis, Prentice Hall, Upper Saddle River, NJ, USA, 1958.
[25] M. Witkamp and J. van der Drift, "Breakdown of forest litter in relation to environmental factors," Plant and Soil, vol. 15, no. 4, pp. 295-311, 1961.

[26] J. B. Jones, B. Wolf, and H. A. Mills, "Interpretation of results," in Plant Analysis Handbook-A Practical Sampling, Preparation, Analysis and Interpretation Guide, Micro-Macro Publishing, Athens, Ga, USA, 1991.

[27] V. G. Panse and P. V. Sukuhatme, Statistical Methods for Agricultural Workers, ICAR, New Delhi, India, 1985.

[28] S. K. Tripathi, A. Sumida, H. Shibata et al., "Leaf litterfall and decomposition of different above- and belowground parts of birch (Betula ermanii) trees and dwarf bamboo (Sasa kurilensis) shrubs in a young secondary forest in Northern Japan," Biology and Fertility of Soils, vol. 43, no. 2, pp. 237-246, 2006.

[29] R. R. Pandey, G. Sharma, S. K. Tripathi, and A. K. Singh, "Litterfall, litter decomposition and nutrient dynamics in a subtropical natural oak forest and managed plantation in Northeastern India," Forest Ecology and Management, vol. 240, no. 1-3, pp. 96-104, 2007.

[30] V. Meentmeyer, E. O. Box, and R. Thompson, "World patterns and amounts of terrestrial plant litter production," Bioscience, vol. 32, no. 2, pp. 125-128, 1982.

[31] J. R. Bray and E. Gorham, "Litter production in forests of the world," Advances in Ecological Research, vol. 2, pp. 101-157, 1964.

[32] B. Berg and C. McClaugherty, Plant Litter: Decomposition, Humus Formation, Carbon Sequestration, Springer, Berlin, Germany, 2003.

[33] A. Gallardo and J. Merino, "Leaf decomposition in two Mediterranean ecosystems of southwest Spain: influence of substrate quality," Ecology, vol. 74, no. 1, pp. 152-161, 1993.

[34] M. E. Pérez-Corona, M. C. Pérez Hernández, and F. B. de Castro, "Decomposition of alder, ash, and poplar litter in a Mediterranean riverine area," Communications in Soil Science and Plant Analysis, vol. 37, no. 7-8, pp. 1111-1125, 2006.

[35] K. G. van Geffen, M. P. Berg, and R. Aerts, "Potential macrodetritivore range expansion into the subarctic stimulates litter decomposition: a new positive feedback mechanism to climate change?" Oecologia, vol. 167, no. 4, pp. 1163-1175, 2011.

[36] S. K. Tripathi and K. P. Singh, "Abiotic and litter quality control during the decomposition of different plant parts in dry tropical bamboo savanna in India," Pedobiologia, vol. 36, no. 4, pp. 241$256,1992$.

[37] L. Alhamd, S. Arakaki, and A. Hagihara, "Decomposition of leaf litter of four tree species in a subtropical evergreen broad-leaved forest, Okinawa Island, Japan," Forest Ecology and Management, vol. 202, no. 1-3, pp. 1-11, 2004.

[38] V. Jamaludheen and B. M. Kumar, "Litter of multipurpose trees in Kerala, India: variations in the amount, quality, decay rates and release of nutrients," Forest Ecology and Management, vol. 115, no. 1, pp. 1-11, 1999.

[39] B. R. Taylor, W. F. J. Parsons, and D. Parkinson, "Decomposition of Populus tremuloides leaf litter accelerated by addition of Alnus crispa litter," Canadian Journal of Forest Research, vol. 19, no. 5, pp. 674-679, 1989.

[40] C. E. Prescott, "Decomposition and mineralization of nutrients from litter and humus," in Nutrient Acquisition by Plants: An Ecological Perspective, H. BassiriRad, Ed., vol. 181 of Ecological Studies, pp. 15-41, 2005.

[41] P. Pande, Y. S. Rawat, and S. P. Singh, "Litter fall, decomposition and seasonal changes in nutrient concentration in decomposing litter in Arundinaria falcata in Oak zone on Central Himalaya. 
High altitude of the Himalaya-II, biodiversity," Ecology 'Environment, vol. 2, pp. 415-426, 2000.

[42] G. Sjöberg, S. I. Nilsson, T. Persson, and P. Karlsson, "Degradation of hemicellulose, cellulose and lignin in decomposing spruce needle litter in relation to N," Soil Biology and Biochemistry, vol. 36, no. 11, pp. 1761-1768, 2004.

[43] C. Körner, Alpine Plant Life: Functional Plant Ecology of High Mountain Ecosystem, Springer, Berlin, Germany, 2003.

[44] B. Berg and R. Laskowski, Litter Decomposition: A Guide to Carbon and Nutrient Turnover, Elsevier Academic Press, San Diego, Calif, USA, 2006.

[45] S. K. Tripathi and K. P. Singh, "Nutrient immobilization and release patterns during plant decomposition in a dry tropical bamboo savanna, India," Biology and Fertility of Soils, vol. 14, no. 3, pp. 191-199, 1992. 

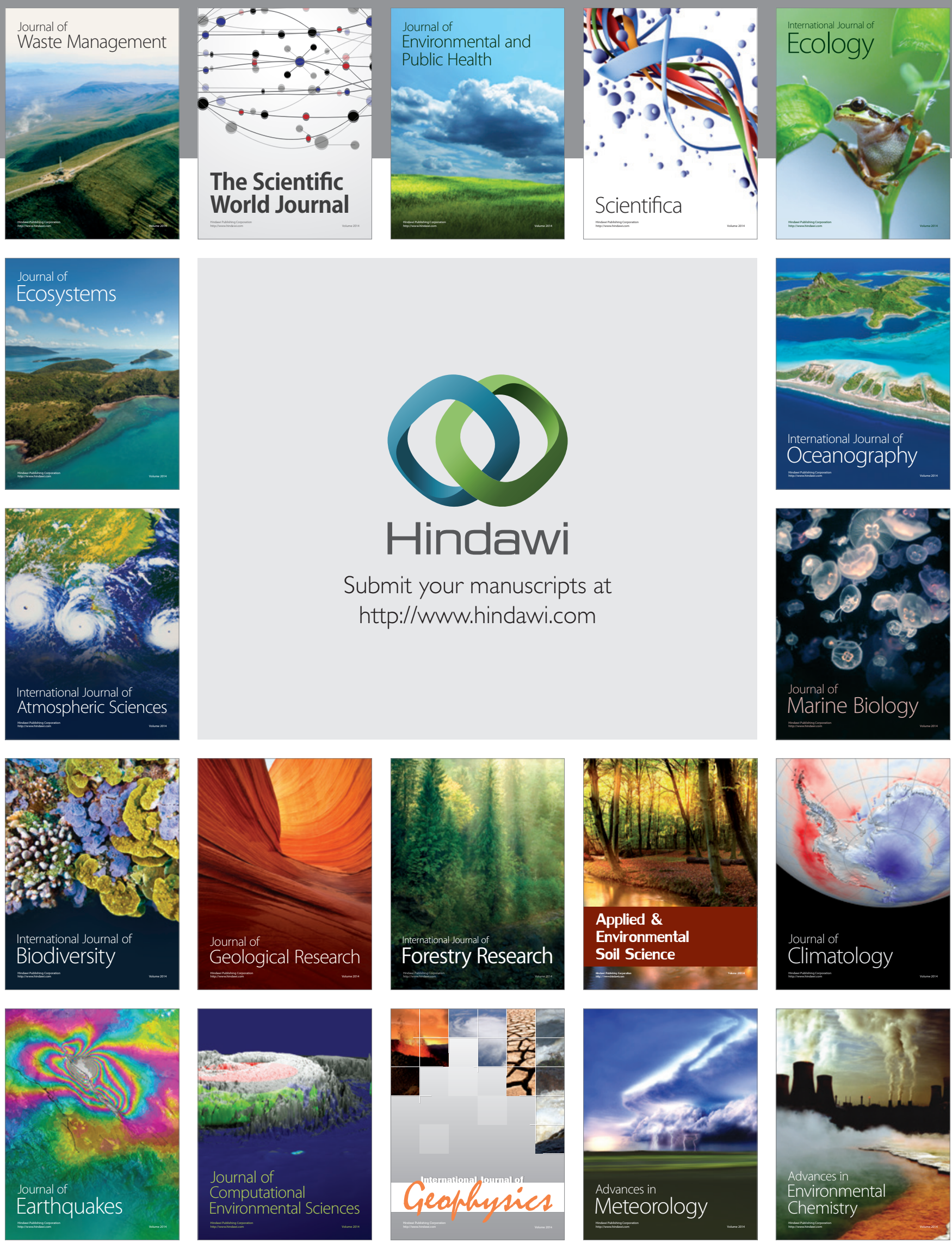